\title{
ע Onko masennus lisääntynyt suomalaisessa aikuisväestössä?
}

Maailmanlaajuisesti masennuksen esiintyvyys ei ole muuttunut viime vuosikymmeninä. Suomessa masennushäiriöiden esiintyvyys edustavissa väestötutkimuksissa oli vuonna 2000 7,3\% ja vuonna 2011 9,6\%. Esiintyvyyden kasvu oli merkitsevä naisilla, mutta ei miehillä. Masennuslääkkeiden kulutus ja erikoissairaanhoidon polikliiniset käynnit masennuksen vuoksi ovat myös lisääntyneet 2000-luvulla, kun taas sairaalahoito on vähentynyt. Masennushäiriöiden hoito on lisääntynyt enemmän kuin esiintyvyys, mikä viittaa siihen, että entistä useampi osaa hakeutua oireiden vuoksi hoitoon.

Masennushäiriöiden esiintyvyyden vertailua vaikeuttavat mittaus- ja haastattelumenetelmien erot ja osallistumisaktiivisuuden vaihteluun liittyvä valikoitumisharha. Masennushäiriöiden esiintyvyys Suomessa on jonkin verran korkeampi kuin maailmanlaajuinen keskiarvo, mutta lukuja vertailtaessa on otettava huomioon, että suomalaisissa esiintyvyysarvioissa on korjattu valikoitumisharhan vaikutusta moni-imputoinnilla, toisin kuin useimmissa muissa tutkimuksissa. Siksi voidaan päätellä, että masennuksen esïntyvyys Suomessa ei todennäköisesti ole poikkeuksellisen korkea verrattuna muihin länsimaihin.

Masennuksen esiintyvyyden muutokset voivat heijastaa muita yhteiskunnallisia muutoksia. Erityisesti talouden laskusuhdanteilla on usein kielteisiä seurauksia mielenterveydelle. Masennuksen ilmeinen yleistyminen suomalaisilla naisilla on tapahtunut samaan aikaan 2010-luvun taloudellisen taantuman kanssa. On kuitenkin mahdollista, että masennushäiriöiden nykyiseen esiintyvyyteen vaikuttaa myös 1990-luvun lama, sillä lapsena koetut vaikeudet ovat voimakas riskitekijä masennushäiriöiden kehittymiselle.

Masennushäiriöiden lisääntyminen Suomessa erityisesti naisten keskuudessa edellyttää tarkempia tutkimuksia ja toimenpiteitä tämän huolestuttavan kehityksen muuttamiseksi.

\section{ASIASANAT: masennus, masennushäiriö, väestötutkimus, esiintyvyys}

\section{NIINA MARKKULA, JAANA SUVISAARI}

\section{JOHDANTO}

Masennus on kansanterveydellisesti merkittävimpiä mielenterveyshäiriöitä koko maailmassa: masennushäiriöt aiheuttavat $40 \%$ koko mielenterveyshäiriöiden globaalista tautitaakasta (1). Tähän vaikuttaa sekä niiden yleisyys että merkittävästi elämänlaatua heikentävät oireet. Masennukseen liittyy kaksinkertainen kuolinriski, joka koostuu sekä lisääntyneestä tautikuolleisuudesta että itsemurhista (2). Usein masennus heikentää työ- ja toimintakykyä merkittävästi, ja on riski pysyvään työkyvyttömyyteen (3). Masennushäiriöiden tautitaakan ja seurausten arvioimiseksi on tärkeää tietää, kuinka suurta osaa väestöstä ne koskettavat.

Masennushäiriöiden esiintyvyyden muutokset kiinnostavat yleisellä tasolla, ja niiden voidaan tulkita heijastavan mahdollisia muita yhteiskun- 
nallisia muutoksia. Masennuksen esiintyvyyden mittaaminen ja tulkinta on kuitenkin haastavaa: pienet muutokset käytetyissä haastattelumenetelmissä tai tutkimusotoksessa voivat johtaa siihen, että kahta tutkimusta ei voikaan verrata keskenään (4). Näitä vaikeuksia voidaan kuitenkin korjata tilastollisin menetelmin ja ottaa huomioon tulkinnassa. Masennushäiriöiden esiintyvyyden tutkiminen auttaa paitsi kohdentamaan terveydenhuollon resursseja, myös ymmärtämään tarkemmin näihin häiriöihin vaikuttavia tekijöitä.

\section{MASENNUSHÄIRIÖT}

Yleisimpiä masennushäiriöitä ovat masennustila (major depressive disorder, MDD) ja pitkäaikainen masennus eli dystymia. Näiden häiriöiden diagnostiset kriteerit on määritelty lääketieteessä yleisesti käytössä olevassa International Classification of Diseases (ICD)- ja psykiatrisiin häiriöihin keskittyneessä Diagnostic and Statistical Manual of Mental Disorders (DSM) -luokituksissa $(5,6)$. Masennustilassa esiintyy vähintään kahden viikon ajan vähintään neljä (ICD-luokitus) tai viisi (DSM-luokitus) oiretta, ja dystymiassa 3-4 oiretta vähintään kahden vuoden ajan. Masennushäiriöiden keskeisimmät oireet ovat masentunut mieliala, kyvyttömyys kokea mielihyvää ja poikkeuksellinen väsymys. Joissain tutkimuksissa masennushäiriöihin lasketaan mukaan myös tarkemmin määrittämätön masennus, joka ei täytä kahden edellä mainitun häiriön diagnostisia kriteereitä.

\section{MASENNUKSEN ESIINTYYYYDEN MITTAAMISEEN VAIKUTTAVIA MENETELMÄLLISIÏA TEKIJÖITÄ JA HAASTEITA}

\section{TUTKIMUSMENETELMÄT}

Masennuksen esiintyvyyttä tutkivissa väestötutkimuksissa tarvitaan menetelmiä, jotka mittaavat masennuksen oireita luotettavasti ja joita voidaan toistaa tuhansille ihmisille samalla tavoin. Parhaiten nämä kriteerit täyttävä menetelmä on strukturoitu, usein tietokoneavusteinen, haastattelu, jonka voi suorittaa koulutuksen saanut henkilö, joka ei ole mielenterveyden ammattilainen. Varhaisia kansainvälisiä vertailevia tutkimuksia tehtiin 1990-luvun alussa Diagnostic Interview Schecule (DIS) -instrumentilla (7). Nykyään yleisimmin käytetty on Composite International Diagnostic
Interview eli CIDI. Monissa tutkimuksissa käytetään myös itse täytettäviä, oireita kartoittavia kyselylomakkeita, joissa tietyn pistemäärän perusteella puhutaan kliinisesti merkittävistä masennusoireista. Tämä menetelmä ei kuitenkaan vastaa strukturoidun haastattelun antamaa masennushäiriödiagnoosia. Arviointimenetelmän valinta vaikuttaa havaittuun esiintyvyyteen.

Maailman tautitaakkaa arvioivan Global Burden of Disease -tutkimusta varten tehtiin laaja kirjallisuuskatsaus masennuksen esiintyvyydestä (8). Metaregression avulla arvioitiin, mitkä tutkimuksen piirteet vaikuttivat havaittuun esiintyvyyteen. Näitä tekijöitä olivat tutkitun esiintyvyyden aikaikkuna, otoksen ikä- ja sukupuolijakauma, sisällytetyt masennushäiriödiagnoosit, sekä käytetty mittausmenetelmä. Havaittu esiintyvyys oli suurempi, kun mitattiin vuotuista eikä hetkellistä esiintyvyyttä, kun sisällytettiin määrittelemätön masennus masennustilan lisäksi, ja kun käytettiin oirepohjaisia kyselylomakkeita eikä diagnoosikriteereihin perustuvia haastatteluja.

\section{MUISTIN EPÄTARKKUUS}

Taaksepäin katsovat tutkimukset masennuksen elämänaikaisesta esiintyvyydestä eivät ole kovin luotettavia, koska tutkittavilla on vaikeuksia muistaa aikaisempia masennusjaksoja ja niiden oireita yksityiskohtaisesti. Etenevissä tutkimuksissa havaitut elämänaikaiset esiintyvyysarviot ovat olleet kolme kertaa suurempia kuin taaksepäin katsovien tutkimuksissa $(9,10)$. Toisaalta etenevissä tutkimuksissa seurataan usein syntymäajan ja -paikan suhteen rajattua joukkoa, kohorttia, jolloin mahdollista kohorttivaikutusta eli ilmiön liittymistä nimenomaan tiettynä aikana syntyneeseen sukupolveen ja tulosten yleistettävyyttä on vaikea arvioida. Tämän vuoksi vertailtaessa masennushäiriöiden esiintyvyyttä on luotettavampaa rajata tarkastelu koko väestöstä tehtyyn satunnaisotantaan perustuviin tutkimuksiin ja vuotuiseen tai hetkelliseen esiintyvyyteen kuin elämänaikaiseen esiintyvyyteen.

\section{KATO JA VALIKOITUMISHARHA}

Toinen haaste psykiatrisessa epidemiologiassa on kadon huomioiminen: psykiatrisista häiriöistä kärsivät osallistuvat väestötutkimuksiin selvästi terveitä henkilöitä harvemmin (11). Tämä osallistumisaktiivisuuteen liittyvä valikoitumisharha todennäköisesti aiheuttaa sen, että väestötutki- 
muksista saadut esiintyvyysarviot ovat todellisia matalampia. Suomalaisessa kohorttitutkimuksessa, jossa mielenterveyshäiriöistä saatiin tietoa valtakunnallisista terveysrekistereistä, kaikkiin mielenterveyshäiriöihin liittyi alhaisempi tutkimukseen osallistumisaktiivisuus (11). Osallistumisaktiivisuuteen voivat vaikuttaa esimerkiksi sairauden oireet, muistivaikeudet tai muut toiminnan ongelmat tai sosiaalisen tuen puute. Myös päinvastainen valikoitumisharha on mahdollinen: kiireiset, terveyteensä tyytyväiset kansalaiset eivät välttämättä ole kiinnostuneita osallistumaan väestötutkimuksiin. Toistaiseksi tästä ei ole Suomessa näyttöä (12), mutta väestötutkimusten vastausaktiivisuuden jatkuvasti heikentyessä tämäkin mahdollisuus on huomioitava.

Valikoitumisharhan vaikutus esiintyvyysarvioihin voidaan korjata erilaisin menetelmin, kuten painokertoimilla tai moni-imputoinnilla, joista jälkimmäinen on toteutukseltaan monimutkaisempi mutta tehokkaampi menetelmä (13). Painokertoimilla voidaan väestötutkimuksissa korjata kadosta johtuvaa tiettyjen väestöryhmien, kuten vanhimpien ja nuorimpien ikäryhmien tai vähemmän koulutettujen aliedustusta. Yleisesti käytetty menetelmä on jälkiositus, jossa tutkimukseen osallistuneiden henkilöiden tietoja painotetaan väestöjakaumalla määrättyjen ominaisuuksien (esimerkiksi ikä ja sukupuoli) mukaan. Moni-imputointi on tilastollinen menetelmä, jossa paikataan puuttuvia havaintoja käyttämällä hyväksi tietoja, jotka korreloivat puuttuvan havainnon kanssa. Sosiodemografisten tietojen lisäksi voidaan käyttää esimerkiksi rekisteritietoja tai muita tutkimushenkilöistä olemassa olevia tietoja.

\section{DIAGNOSTISTEN KRITEEREIDEN MERKITYS}

Laajassa meta-analyysissa havaittuun masennushäiriöiden esiintyvyyteen ei vaikuttanut se, käytettiinkö DSM- vai ICD-luokitusta, vaikka DSM:ssa masennustilan diagnoosiin vaaditaan viisi oiretta, kun taas ICD-luokituksessa neljä oiretta riittää (8). Australialaisessa väestötutkimuksessa vertailtiin masennushäiriöiden esiintyvyyttä molemmilla luokituksilla, ja ICD-luokituksella esiintyvyys oli 0.2-0.6 prosenttiyksikköä korkeampi. Ero ei johtunut ns. kliinisen merkitsevyyden kriteeristä, joka sisältyy DSM- mutta ei ICD-luokitukseen: kaikki, jotka täyttivät muut oirekriteerit, kokivat oireiden aiheuttavan merkittävää haittaa tai kärsimystä (14) .

DSM-luokitus päivitettiin viidenteen versioonsa vuonna 2013, ja tulevan ICD-11:n odotetaan mukailevan ainakin osaa näistä muutoksista. Masennushäiriöiden kohdalla suurin muutos DSM-IV:stä DSM-5:een siirryttäessä on suruaikaan liittyvän poissulkukriteerin poistaminen: DSM-5 määrittelee masennuksen diagnoosin oireiden perusteella riippumatta siitä, johtuvatko nämä oireet läheisen kuolemasta tai jostain muusta tapahtumasta $(15,16)$. Toinen muutos DSM-5:n siirryttäessä oli dystymian korvaaminen persistent depressive disorder -diagnoosilla, joka sisältää dystymian lisäksi myös kroonisen masennustilan. Dystymian oirekriteerit eivät muuttuneet olennaisesti.

On epävarmaa, miten nämä muutokset vaikuttavat havaittuun masennuksen esiintyvyyteen (16). Eräässä tutkimuksessa 38\% lyhytkestoisesta (alle $2 \mathrm{kk}$ ) masennustilasta kärsivistä raportoi oireiden johtuvan läheisen kuolemasta. Näin ollen havaittu masennuksen esiintyvyys voisi nousta paljonkin, jos nämä tapaukset aiemmasta poiketen määritelläänkin masennustilaksi (17).

\section{ONKO MASENNUS LISÄÄNTYNYT MAAILMASSA?}

Tuoreiden meta-analyysien perusteella masennuksen hetkittäinen esiintyvyys maailmassa on noin $5 \%(8,18)$. Näissä katsauksissa on yhdistetty sekä tutkimuksia, jotka ovat mitanneet nimenomaan masennustilan että kaikkien masennushäiriöiden esiintyvyyttä joko haastatteluja tai oiremittareita hyväksi käyttäen. Masennustilaan verrattuna harvat tutkimukset ovat selvittäneet dystymian esiintyvyyttä, mutta käytettävissä olevista tutkimuksista tehdyn meta-analyysin mukaan sen vuotuinen esiintyvyys on 1,6\% (19).

Monissa maissa on havaittu merkkejä, jotka viittaavat masennuksen esiintyvyyden lisääntymiseen: esimerkiksi masennuslääkkeiden käytön tai masennukseen perustuvien sairauslomien lisääntymistä (20-22). Tämä on johtanut käsitykseen siitä, että masennuksen esiintyvyys on lisääntynyt.

Maailmassa masennuksen hetkittäinen esiintyvyys on kuitenkin pysynyt samalla tasolla vuosina 1990 ja 2010 (23) (Taulukko 1). Kanadassa masennuksen esiintyvyyttä on tutkittu kahden vuoden välein vuodesta 1994 alkaen (4). Tänä 
Taulukko 1: Masennushäiriöiden esiintyvyys valituissa tutkimuksissa.

\begin{tabular}{|lllr|}
\hline Tutkimuspaikka & Aiempi vuotuinen esiintyvyys & Viimeisin vuotuinen esiintyvyys & Viite \\
\hline Globaali esiintyvyys & $1990: 4.4 \%$ & $2010: 4.4 \%$ & $(19)$ \\
Alankomaat & $1996: 7.4 \%$ & $2007-09: 6.1 \%$ & $(24)$ \\
Yhdysvallat & $1990-92: 8.6 \%$ & $2001-036.6 \%$ & $(25)$ \\
Yhdysvallat & $1990-91: 3.3 \%$ & $2001-02: 7.1 \%$ & $(26)$ \\
Kanada & $1994: 5.6 \%$ & $2011: 7.3 \%$ & $(4)$ \\
Suomi & $2000: 7.3 \%$ & $2011: 9.6 \%$ & $(29)$ \\
\hline
\end{tabular}

aikana keskimäärin 5,5\%:n vuosittaisessa esiintyvyydessä ei tapahtunut tilastollisesti merkitsevää vaihtelua.

Alankomaissa mielialahäiriöiden esiintyvyyttä mitattiin kahdessa menetelmiltään samanlaisessa väestötutkimuksessa (24). Vuonna 1996 mielialahäiriöiden vuotuinen esiintyvyys oli 7,4\% ja 2007-2009 6,1\%. Kun otettiin huomioon väestörakenteen muutos - ikääntyminen sekä koulutus- ja työllisyysasteen nousu - esiintyvyyden lasku ei ollut merkitsevä.

Yhdysvalloissa tutkittiin mielenterveyshäiriöiden esiintyvyyttä väestötutkimuksissa vuosina 1990-92 ja 2001-03 (25). Tänä aikana masennuksen vuotuinen esiintyvyys laski $8,6 \%$ :sta 6,6\%:iin. Tämän tulkittiin kuitenkin johtuneen mielenterveyshaastattelun menetelmän tarkentumisesta ja väärien positiivisten vähenemisestä. Myös tutkittujen ikä erosi tutkimusten välillä: ensimmäisessä mukana oli 15-54-vuotiaita, kun taas jälkimmäisessä 18-vuotiaita ja sitä vanhempia. Samoina vuosina tehty laajempi, mutta erilaista haastattelumenetelmää käyttänyt tutkimus taas päätyi päinvastaiseen päätelmään: masennus lisääntyi vuoden 1990 3,3\%:sta vuoden 2001 7,1\%:iin (26). Erilaista haastattelumenetelmää lukuun ottamatta ristiriitaan näiden tutkimusten välillä ei löydy ilmeistä selitystä. Tutkimuksissa päädyttiin kuitenkin samankaltaisiin esiintyvyyslukuihin vuoden 2001 osalta, mutta 1990-luvun alun esiintyvyysluvuissa oli suuri ero. Valitettavasti tuoreempia laajoja väestötutkimuksia masennuksen esiintyvyydestä Yhdysvalloissa ei ole tehty.

\section{MASENNUKSEN ESIINTYYYYS SUOMESSA}

Suomessa masennuksen esiintyvyyttä on mitattu ainakin kolmessa kansallisessa väestötutkimuk- sessa vertailukelpoisin menetelmin. Mini-Suomitutkimuksessa vuosina 1978-80 neuroottisen masennuksen vuotuinen esiintyvyys yli 30 -vuotiaiden suomalaisten keskuudessa oli 4,6\% (27). Vuonna 1996 laajassa 15-75-vuotiaiden aikuisten otoksessa masennustilan vuotuinen esiintyvyys oli 9,3\%, mutta käytetty mittari (UM-CIDI short form) ei erottele esimerkiksi orgaanisista syistä johtuvia masennusoireita tai eri masennushäiriöitä toisistaan (28).

Laajat väestötutkimukset Terveys 2000 ja sen seurantatutkimus Terveys 2011 selvittivät masennus-, ahdistus- ja alkoholihäiriöiden esiintyvyyttä strukturoidulla CIDI-haastattelulla. Otos edusti koko 30-vuotiasta tai sitä vanhempaa Suomen väestöä. Vuonna 2000 mielenterveyshaastatteluun osallistui 6005 henkilöä (75\% otoksesta) ja vuonna 20114478 henkilöä (55\% otoksesta).

Terveys 2011 -tutkimuksen osallistumisaktiivisuus oli Terveys 2000 -tutkimusta matalampi, mikä vaikeuttaa näiden tulosten vertailua. Kadon aiheuttamaa harhaa korjattiin kahdella menetelmällä: painokertoimilla sekä moni-imputoinnin avulla käyttämällä hyväksi rekisteritietoja psykiatrisista sairaalahoidoista. Katoon jääneissä olivat yliedustettuna henkilöt, joilla on psykiatrisia sairauksia: rekisteritiedoista kävi ilmi, että $61 \%$ henkilöistä, joilla oli elämän aikana ollut sairaalahoito masennuksen vuoksi, ei osallistunut tutkimukseen (Taulukko 2) (29).

Moni-imputoinnilla korjatut esiintyvyysarviot olivat noin kaksi prosenttiyksikköä korkeampia kuin painokertoimilla korjatut (Taulukko 3). Tämä on ymmärrettävää, koska painokertoimissa rekisteritietoja psykiatrisista sairaalahoidoista ei ollut käytetty hyväksi. Esiintyvyyden muutoksen arviointia varten myös vuoden 2000 tiedot korjattiin moni-imputoinnilla. 
Taulukko 2: Psykiatrisessa sairaalahoidossa olleiden osuus mielenterveyshaastatteluun osallistuneista ja katoon jääneistä Terveys 2000- ja 2011 -tutkimuksissa.

\begin{tabular}{|c|c|c|c|c|c|c|c|c|}
\hline & \multicolumn{4}{|c|}{ Terveys 2000} & \multicolumn{4}{|c|}{ Terveys 2011} \\
\hline & \multicolumn{2}{|c|}{$\begin{array}{l}\text { Psykiatrinen } \\
\text { sairaalahoito }(\%)^{1}\end{array}$} & \multicolumn{2}{|c|}{$\begin{array}{l}\text { Sairaalahoito } \\
\text { masennuksen vuoksi } \\
(\%)^{2}\end{array}$} & \multicolumn{2}{|c|}{$\begin{array}{l}\text { Psykiatrinen } \\
\text { sairaalahoito }(\%)^{1}\end{array}$} & \multicolumn{2}{|c|}{$\begin{array}{l}\text { Sairaalahoito } \\
\text { masennuksen vuoksi } \\
(\%)^{2}\end{array}$} \\
\hline & \multicolumn{4}{|c|}{ Osallistunut mielenterveyshaastatteluun } & \multicolumn{4}{|c|}{ Osallistunut mielenterveyshaastatteluun } \\
\hline & Kyllä & $\mathrm{Ei}$ & Kyllä & $\mathrm{Ei}$ & Kyllä & $\mathrm{Ei}$ & Kyllä & $\mathrm{Ei}$ \\
\hline $\begin{array}{l}\text { Kaikki } \\
\text { ikäryhmät }\end{array}$ & 7.1 & 10.3 & 1.0 & 1.9 & 7.5 & 12.8 & 1.8 & 3.2 \\
\hline $30-45$-v. & 6.0 & 12.8 & 0.8 & 1.9 & 7.0 & 10.0 & 1.3 & 2.6 \\
\hline $45-55-\mathrm{v}$ & 8.0 & 15.9 & 1.7 & 1.2 & 8.3 & 13.6 & 1.7 & 3.8 \\
\hline $55-65-\mathrm{v}$ & 7.7 & 14.6 & 0.7 & 2.2 & 8.5 & 16.3 & 2.6 & 3.0 \\
\hline $65-75-\mathrm{v}$ & 8.1 & 19.8 & 1.2 & 2.1 & 6.4 & 14.5 & 1.6 & 3.6 \\
\hline 75 -v. + & 5.7 & 12.7 & 0.9 & 4.7 & 5.9 & 14.5 & 1.5 & 4.6 \\
\hline
\end{tabular}

1. Mikä tahansa psykiatrinen sairaalahoito elinaikana

2. Sairaalahoito masennuksen vuoksi elinaikana

Terveys 2000 -tutkimuksessa masennustila todettiin 5,9\%:lla 30-vuotiaasta tai sitä vanhemmasta väestöstä, dystymia 3,8\%:lla ja kumpi tahansa masennushäiriö 7,3\%:lla, kun kadon vaikutus otettiin huomioon moni-imputoinnilla (30) (Taulukko 3). Terveys 2011 -tutkimuksessa masennustilan vuotuinen esiintyvyys samassa ikäryhmässä oli 7,4\%, dystymian 4,5\% ja kumman tahansa masennushäiriön 9,6\% (30). Esiintyvyyden kasvu oli tilastollisesti merkitsevä naisilla mutta ei miehillä. Esiintyvyyden kasvu on havaittavissa myös painokertoimilla korjatuissa luvuissa, mutta ei ollut tilastollisesti merkitsevä $(\mathrm{P}=0,057)$. Ottaen huomioon kadon valikoivuus, on todennäköistä, että moni-imputoinnilla korjatut luvut ovat lähempänä masennushäiriöiden todellista esiintyvyyttä.

\section{ONKO SUOMI EPÄTAVALLISEN MASENTUNUT MAA?}

Masennustilan vuotuinen esiintyvyys, $7,4 \%$, on korkeampi kuin globaaleissa katsauksissa havaittu 5\% $(8,18)$, mutta lähellä Euroopan maiden keskiarvoa, 6,9\% (31). Dystymian esiintyvyys, $4,5 \%$, on huomattavasti korkeampi kuin globaali keskiarvo 1,6\% (19) tai esimerkiksi USA:ssa, Alankomaissa, Australiassa ja Saksassa havaitut $1,1-2,5 \%(14,24,32,33)$.

Vertailussa on kuitenkin otettava huomioon, että vain painokertoimilla korjattu masennusti- lan esiintyvyys oli 5,4\% ja dystymian 2,0\%. Valtaosassa muista tutkimuksista kadon vaikutus on korjattu painokertoimilla. Tämä huomioon ottaen ei voi sanoa, että masennushäiriöiden esiintyvyys Suomessa olisi poikkeavan suuri.

\section{MUITA TIETOJA MASENNUKSEN YLEISYYDESTÄ}

\section{KOULUTERVEYSKYSELY}

Samaan aikaan on havaittu myös nuorten masennusoireiden lisääntyneen Suomessa alemmissa sosioekonomisissa ryhmissä (34). Kahden vuoden välein toteutettava kouluterveyskysely kerää tietoa nuorten elinoloista, koulun olosuhteista, koetusta terveydestä ja terveystottumuksista. Masennusoireita kartoitetaan Beckin masennuskyselyn lyhennetyllä versiolla (12 kysymyksen R-BDI). Kyselyyn vastaa noin 200000 peruskoulujen 8.-9. luokan oppilasta sekä lukioiden ja ammatillisten oppilaitosten 1.-2. vuoden opiskelijaa oppituntien aikana. Vastausaktiivisuus on hyvä, noin $85-90 \%$.

Masennusoireiden esiintyvyyttä tutkittiin 8.-9.-luokkalaisten otoksessa vuosina 20002011. Vakavia masennusoireita oli vuonna 2000 2001 4,0\%:Ila tytöistä ja 2,1\%:Ila pojista. Vuonna 2010-2011 vastaavat luvut olivat 4,7\% ja $2,2 \%$. Kun tarkasteltiin nuoria, joiden vanhem- 
Taulukko 3. Masennushäiriöiden esiintyvyys Terveys 2000- ja 2011-tutkimuksissa

\begin{tabular}{|c|c|c|c|c|c|c|}
\hline & \multicolumn{3}{|c|}{ Moni-imputoidut tulokset } & \multicolumn{3}{|c|}{ Painokertoimilla lasketut tulokset } \\
\hline & $\begin{array}{l}\text { Terveys } 2000 \\
(\mathrm{n}=6005)^{1}\end{array}$ & $\begin{array}{l}\text { Terveys } 2011 \\
(\mathrm{n}=4478)\end{array}$ & $\mathrm{p}$ & $\begin{array}{l}\text { Terveys } 2000 \\
(\mathrm{n}=6005)^{1}\end{array}$ & $\begin{array}{l}\text { Terveys } 2011 \\
(\mathrm{n}=4478)\end{array}$ & $\mathrm{p}$ \\
\hline \multicolumn{7}{|l|}{ Masennustila } \\
\hline Koko väestö & $5.9 \%$ & $7.4 \%$ & 0.133 & $4.6 \%$ & $5.3 \%$ & 0.057 \\
\hline Miehet & $3.5 \%$ & $4.4 \%$ & 0.777 & $3.0 \%$ & $3.5 \%$ & 0.518 \\
\hline Naiset & $8.0 \%$ & $10.0 \%$ & 0.049 & $6.0 \%$ & $7.0 \%$ & 0.063 \\
\hline \multicolumn{7}{|l|}{ Dystymia } \\
\hline Koko väestö & $3.8 \%$ & $4.5 \%$ & 0.426 & $2.4 \%$ & $2.0 \%$ & 0.246 \\
\hline Miehet & $3.7 \%$ & $4.4 \%$ & 0.283 & $1.9 \%$ & $1.6 \%$ & 0.949 \\
\hline Naiset & $3.9 \%$ & $4.6 \%$ & 0.951 & $2.8 \%$ & $2.4 \%$ & 0.128 \\
\hline \multicolumn{7}{|l|}{ Masennushäiriö } \\
\hline Koko väestö & $7.3 \%$ & $9.6 \%$ & 0.014 & $6.1 \%$ & $6.8 \%$ & 0.122 \\
\hline Miehet & $4.9 \%$ & $6.5 \%$ & 0.323 & $4.2 \%$ & $4.7 \%$ & 0.229 \\
\hline Naiset & $9.5 \%$ & $12.4 \%$ & 0.018 & $7.8 \%$ & $8.7 \%$ & 0.303 \\
\hline
\end{tabular}

1. Tuloksissa otettu huomioon väestörakenteen muutokset ja korjattu ne vastaamaan vuoden 2011 rakennetta vertailun mahdollistamiseksi

mat olivat matalasti koulutettuja ja työttömiä, vakavien masennusoireiden esiintyvyys lähes kaksinkertaistui seuranta-aikana: tytöillä vuoden 2000 6,4\%:sta vuoden 2011 11,5\%:iin, ja pojilla $6,5 \%$ :sta 12,8\%:iin. Vuonna 2011 nuorilla, joiden vanhemmat olivat matalasti koulutettuja ja työttömiä, vakavien masennusoireiden riski oli 5-10-kertainen verrattuna nuoriin, joiden vanhemmat olivat työssäkäyviä ja korkeasti koulutettuja. Nämä erot kasvoivat selvästi vuodesta 2000 vuoteen 2011. Tutkijat tulkitsivat tämän liittyvän samaan aikaan kasvaneisiin tuloeroihin ja lisääntyneeseen suhteelliseen köyhyyteen Suomessa. Väestötutkimuksista saatua tietoa varsinaisten masennushäiriöiden esiintyvyydestä tai sen muutoksista tässä ikäryhmässä ei valitettavasti ole.

\section{MASENNUSLÄÄKKEIDEN KÄYTTÖ JA PSYKIATRINEN ERIKOISSAIRAANHOITO}

Masennuslääkkeiden käyttö on Suomessa lisääntynyt kaikissa ikäryhmissä 1990-luvun alusta 2010-luvulle asti, ja viime vuosina kääntynyt joissakin ikäryhmissä laskuun (kuvio 1). Tämä muutos on tulkittu johtuvaksi muuttuneista hoitokäytännöistä ja lisääntyneestä hoitoon hakeutumisesta, mutta sen suhde masennuksen esiintyvyyden muutokseen on ollut epäselvä. On tärkeä ottaa huomioon, että masennuslääkkeiden käyt- töindikaatiot ovat laajat, ja niiden käyttömäärät eivät liity pelkästään masennushäiriöiden yleisyyteen tai hoitokäytäntöihin.

Erikoissairaanhoidossa avohoito masennuksen (ICD-10 koodit F32-F33, masennustila ja toistuva masennustila) vuoksi on lisääntynyt viimeisen 10 vuoden aikana sekä koko väestössä että ikäryhmissä 13-17-vuotiaat ja 18-22-vuotiaat, kun taas sairaalahoito on jonkin verran vähentynyt koko väestössä mutta ei nuoremmissa ikäryhmissä (kuvio 2). Erityisesti avohoitokäynnit ovat lisääntyneet suhteessa vielä enemmän kuin masennuksen esiintyvyys, mikä viittaa siihen, että entistä useampi osaa hakeutua oireiden vuoksi hoitoon.

\section{ONKO MASENNUS LISÄÄNTYNYT SUOMESSA?}

Masennushäiriöiden esiintyvyys näyttäisi lisääntyneen Suomessa viime vuosikymmenen aikana. Toistaiseksi tämä havainto perustuu vain kahteen tutkimukseen (Terveys 2000 ja Terveys 2011), ja ilmiötä on syytä selvittää tarkemmin. Vuosien 1978-80 Mini-Suomi-tutkimuksen ja Terveys 2000:n välillä esiintyvyyden muutoksesta (4,6\%:sta 5,9\%:iin) on vaikeampi tehdä päätelmiä, koska käytetyt menetelmät ja diagnoosit eroavat toisistaan.

Terveys 2000 ja 2011 -tutkimuksissa masennushäiriöistä vain masennustilan esiintyvyys li- 
Kuvio 1: Masennuslääkkeiden käyttö eri ikäryhmissä, 1994-2014.

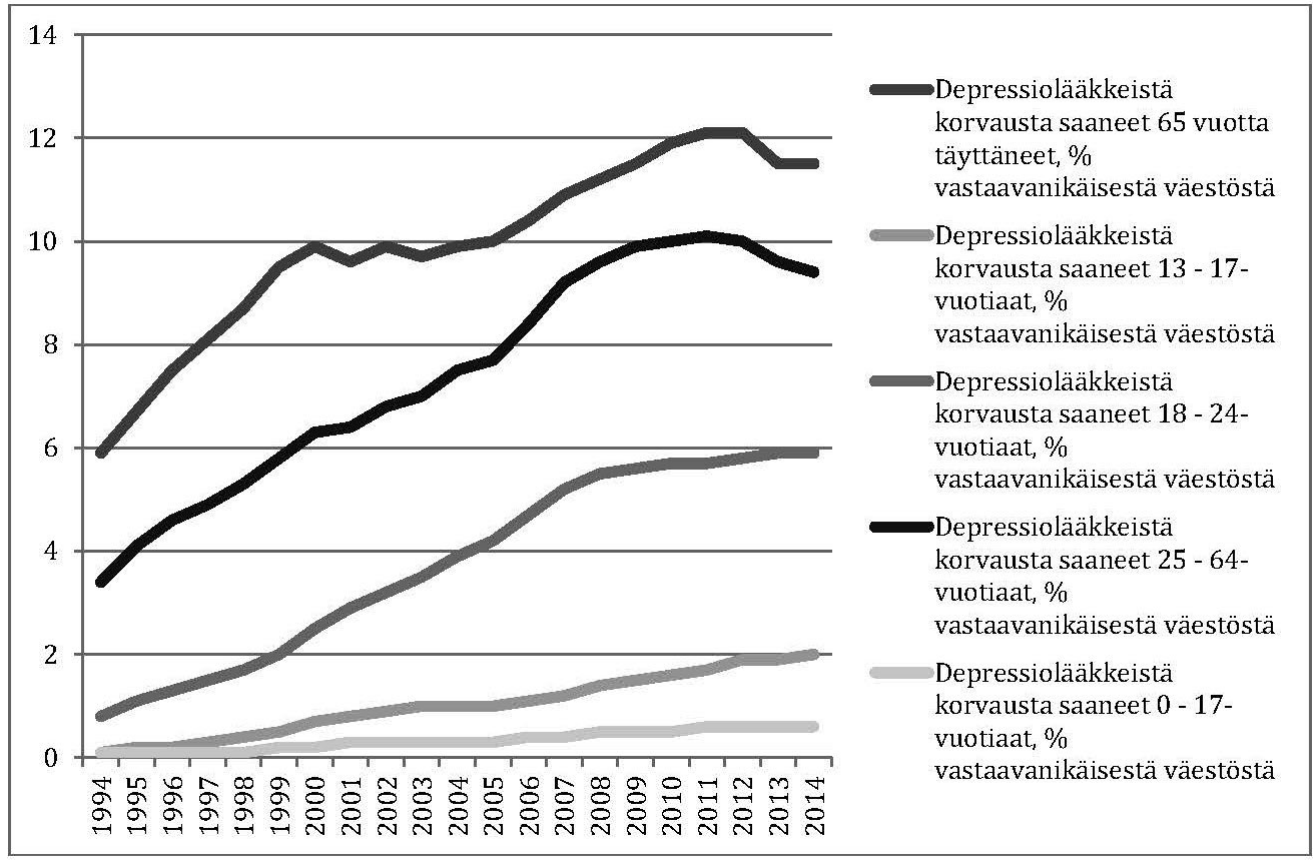

Lähde: Terveyden ja hyvinvoinnin laitos. Sotkanet.fi. Siteerattu 23.9.2016. www.sotkanet.fi/sotkanet/fi/index

sääntyi, kun taas dystymian esiintyvyys pysyi vakaana. Masennustilan esiintyvyys lisääntyi vain naisilla: vuoden $2000 \quad 8,0 \%$ :sta vuoden 2011 10,0\%:iin (moni-imputoidut tulokset, tilastollisesti merkitsevä muutos), kun taas miehillä esiintyvyys pysyi vakaana.

Selitystä masennushäiriöiden esiintymisen muutoksiin voidaan etsiä esimerkiksi ympäröivän yhteiskunnan muutoksista. Erityisesti talouden nousu- ja laskusuhdanteiden vaikutus mielenterveyteen on kiinnostusta herättävä kysymys.

Vuonna 2000 Suomen talous oli vakaassa kasvussa, kun taas vuonna 2011 elettiin laskusuhdannetta. Taantuma ja talouskriisit yhdistyvät kielteisiin seurauksiin mielenterveydelle (35, 36). Nämä vaikutukset välittyvät mielenterveyteen erityisesti työttömyyden, yksilöllisten talousvaikeuksien, alkoholin käytön kielteisten seurauksien ja perheiden vaikeuksien kautta (35). On mahdollista, että 2000-luvun ensikymmenen lopun talouskriisi vaikutti masennuksen esiintymisen ilmeiseen lisääntymiseen Suomessa.

Edellinen vaikea taantuma koettiin Suomessa 1990-luvun alussa, jolloin monet perheet kokivat työttömyyttä ja taloudellisia vaikeuksia.
Tällaiset lapsena koetut vaikeudet ovat riskitekijä myöhemmälle masennushäiriön kehittymiselle (37,38). Kansallinen syntymäkohortti 1987 -tutkimus on seurannut näiden "laman lasten" terveyttä ja hyvinvointia. Täysi-ikäisyyteen mennessä $14 \%$ heistä oli ollut psykiatrisen erikoissairaanhoidon piirissä (39). Lähes joka viides ikäluokasta ei ole suorittanut peruskoulun jälkeistä tutkintoa; heistä 40 prosentilla on mielenterveysongelmia (40). On mahdollista, että 1990-luvun laman aikana koetut vaikeudet myötävaikuttavat masennuksen esiintymisen lisääntymiseen.

Eräs tekijä, joka voi vaikuttaa havaitun esiintyvyyden lisääntymiseen on lisääntynyt tieto depressiosta ja avoimuus koskien omia ja läheisten mielenterveysongelmia (41). Väestötasolla leimaavat asenteet mielenterveysongelmista kärsiviä kohtaan liittyvät vähäisempään masennuslääkkeiden käyttöön (42). Vaikka Suomessa edelleen esiintyy leimaavia asenteita mielenterveysongelmista kärsiviä kohtaan, valtaosa pitää masennusta hoidettavana lääketieteellisenä tilana (43). Muutokset tiedossa ja asenteissa ovat voineet vaikuttaa siihen, että väestötutkimuksen 
Kuvio 2: Psykiatrinen erikoissairaanhoito masennuksen vuoksi eri ikäryhmissä, 2005-2014.
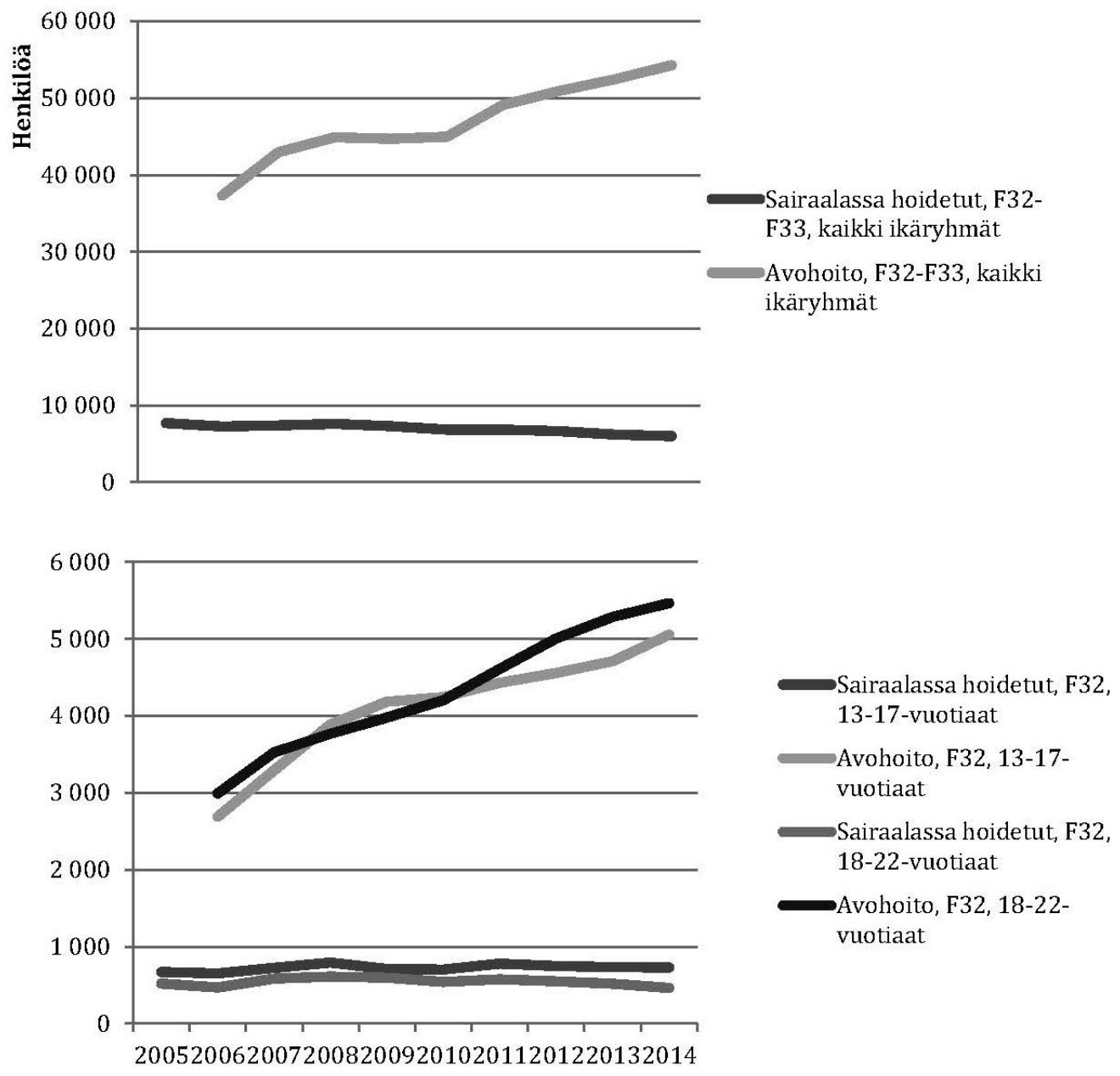

Lähde: Terveyden ja hyvinvoinnin laitos. Psykiatrinen erikoissairaanhoito 2014. Siteerattu 23.9.2016. http://urn.fi/ URN:NBN:fi-fe2016051612397

osallistujat tuovat haastattelussa herkemmin oireita esille.

On mahdotonta osoittaa yhtä tekijää, joka selittäisi masennushäiriöiden mahdollisen lisääntymisen Suomessa. On syytä seurata, saadaanko muissa kotimaisissa ja kansainvälisissä tutkimuksissa samanlaisia tuloksia. Syitä siihen, miksi masennus on lisääntynyt juuri naisten keskuudessa, on myös tutkittava. Muun muassa yksinhuoltajuus (44) ja yksin eläminen (45) on naisten keskuudessa yhdistetty suurempaan masennuksen esiintyvyyteen, ja näitä yhteyksiä tulisi selvittää myös Suomessa.

\section{YHTEENVETO}

Masennus on kansanterveyttä kuormittava yleinen sairaus, jonka seurauksia ovat muun muassa subjektiivinen kärsimys, lisääntynyt kuolleisuus ja työ- ja toimintakyvyn häiriöt. Masennuksen esiintyvyyden muutokset kiinnostavat yleisellä tasolla, ja niiden tulkitaan heijastavan mahdollisia muita yhteiskunnallisia muutoksia. Masennuksen esiintyvyyden ja sen muutosten mittaamiseen liittyy joitakin menetelmällisiä haasteita, jotka vaikeuttavat tulosten tulkintaa. Vuonna 2000 ja 2011 tehtyjen laajojen väestötutkimusten perusteella masennushäiriöt ovat lisääntyneet Suomen 
aikuisväestössä naisten keskuudessa: vuonna 2011 joka kymmenes suomalainen kärsi masennushäiriöstä. Ei ole selvää, mistä masennushäiriöiden lisääntyminen johtuu, mutta kasvun syitä ja suhdetta yhteiskunnallisiin muutoksiin on selvitettävä.
KIRJOITTAJIEN KONTRIBUUTIOT:

Markkula ja Suvisaari ideoivat kirjallisuuskatsauksen ja käsikirjoituksen sisällön yhdessä. Markkula teki taustakirjallisuuden katsauksen, haki käytetyt rekisteritiedot ja laati niistä kuvaajat, kirjoitti ensimmäisen ja sitä seuraavat versiot käsikirjoituksesta. Suvisaari antoi käsikirjoitukseen tärkeitä kommentteja ja hyväksyi lopullisen käsikirjoituksen.

Markkula, N., Suvisaari, J. Trends of depression in the adult population - has the prevalence of depression increased in Finland? Sosiaalilääketieteellinen aikakauslehti - Journal of Social Medicine 20 I 8: 55: I 89-I 99.

Globally, the prevalence of depression has not changed in recent decades. In Finland, the prevalence of depressive disorders in representative population surveys increased from $7.3 \%$ in 2000 to $9.6 \%$ in 2011 . The increase was statistically significant among women, but not among men. Use of anti-depressant drugs and outpatient treatment of depression have also increased in the 2000s, while hospitalization has decreased. Treatment of depressive disorders has increased more than their prevalence, suggesting that more people seek treatment for their symptoms. Measuring changes in the prevalence of depressive disorders is challenging due to differences in interview methods and varying participation activity leading to selection bias. The prevalence of depressive disorders in Finland is somewhat higher than the global average, but when comparing figures, it is important to note that the Finnish prevalence estimates are adjusted for non-participation by using multiple imputation, unlike in most other studies. It can therefore be concluded that the prevalence of depression in Finland is probably not exceptionally high compared to other Western countries.Changes in the prevalence of depression can reflect other societal changes. In particular, economic downturns often have negative consequences for mental health. The apparent increase of depression in Finland has occurred at the same time as the economic recession of the 2010s. However, it is possible that the current prevalence of depressive disorders is also affected by the recession of the 1990s, as childhood adversities are a risk factor for depressive disorders. The increase in the prevalence of depressive disorders in Finland, particularly among women, warrants further study and measures to change this worrying development.

Keywords: depressive disorders; major depressive disorder; dysthymia; prevalence; psychiatric epidemiology

Saapunut 20.10.2017

Hyväksytty 15.1.2018

\section{LÄHTEET}

1. Whiteford H, Degenhardt L, Rehm J, ym. Global burden of disease attributable to mental and substance use disorders: findings from the Global Burden of Disease Study 2010. The Lancet. 2013;S0140-6736(13)61611-6(1474-547X (Electronic)) LID - S0140-6736(13)61611-6 [pii] LID - 10.1016/S0140-6736(13)61611-6 [doi].

2. Walker E, McGee RE, Druss BG. Mortality in mental disorders and global disease burden implications: A systematic review and metaanalysis. JAMA Psychiatry. 2015;72(4):334-41. https://doi.org/10.1001/jamapsychiatry.2014.2502

3. Riihimäki K, Vuorilehto M, Isometsä E. A 5-year

prospective study of predictors for functional and work disability among primary care patients with depressive disorders. European psychiatry : the journal of the Association of European Psychiatrists. 2015;30(1):51-7. https://doi.org/10.1016/j.eurpsy.2014.02.005

4. Patten SB, Williams JV, Lavorato DH, ym. The prevalence of major depression is not changing. Can J Psychiatry. 2015;60(1):31-4. https://doi.org/10.1177/070674371506000107

5. WHO. The ICD-10 Classification of Mental and Behavioural Disorders Diagnostic criteria for research. Geneva; 1993. 
6. American Psychiatric Association. Diagnostic and statistical manual of mental disorders (5th ed.). Washington, DC 2013.

7. Weissman MM, Bland RC, Canino GJ, ym. Crossnational epidemiology of major depression and bipolar disorder. Jama. 1996;276(4):293-9. https://doi.org/10.1001/ jama.1996.03540040037030

8. Ferrari AJ, Somerville A, Baxter AJ, ym. Global variation in the prevalence and incidence of major depressive disorder: a systematic review of the epidemiological literature. Psychol Med. 2013;43(3):471-81.

https://doi.org/10.1017/S0033291712001511

9. Patten SB, Williams JV, Lavorato DH, ym. Recall of recent and more remote depressive episodes in a prospective cohort study. Soc Psychiatry Psychiatr Epidemiol. 2012;47(5):691-6. https://doi.org/10.1007/s00127-011-0385-5

10. Takayanagi Y, Spira AP, Roth KB, ym. Accuracy of reports of lifetime mental and physical disorders: results from the Baltimore Epidemiological Catchment Area study. JAMA Psychiatry. 2014;71(3):273-80. https://doi.org/10.1001/jamapsychiatry.2013.3579

11. Haapea M, Miettunen J, Läärä E, ym. Nonparticipation in a field survey with respect to psychiatric disorders. Scand J Public Health. 2008;36(7):728-36. https://doi.org/10.1177/1403494808092250

12. Tolonen H, Laatikainen T, Helakorpi S, ym. Marital status, educational level and household income explain part of the excess mortality of survey non-respondents. Eur J Epidemiol. 2010;25(2):69-76. https://doi.org/10.1007/s10654-009-9389-9

13. Härkänen T, Karvanen J, Tolonen H, ym. Systematic handling of missing data in complex study designs - experiences from the Health 2000 and 2011 Surveys. Journal of Applied Statistics (accepted for publication). 2016. https://doi.org/10.1080/02664763.2016.1144725

14. Andrews G, Henderson S, Hall WD. Prevalence, comorbidity, disability and service utilisation. Overview of the Australian National Mental Health Survey. 2001;178(2):145-53. https://doi.org/10.1192/bjp.178.2.145

15. Kendler KS, Myers J, Zisook S. Does bereavementrelated major depression differ from major depression associated with other stressful life events? Am J Psychiatry. 2008;165(11):1449-55. https://doi.org/10.1176/appi.ajp.2008.07111757

16. Uher R, Payne JL, Pavlova B, Perlis RH. Major depressive disorder in DSM-5: implications for clinical practice and research of changes from DSM-IV. Depress Anxiety. 2014;31(6):459-71. https://doi.org/10.1002/da.22217

17. McCabe PJ, Christopher PP. Symptom and functional traits of brief major depressive episodes and discrimination of bereavement. Depress Anxiety. 2015.

18. Steel Z, Marnane C, Iranpour C, ym. The global prevalence of common mental disorders: a systematic review and meta-analysis 19802013. International Journal of Epidemiology. 2014;43(2):476-93.

https://doi.org/10.1093/ije/dyu038

19. Charlson FJ, Ferrari AJ, Flaxman AD, Whiteford HA. The epidemiological modelling of dysthymia: Application for the Global Burden of Disease Study 2010. J Affect Disord. 2013;151(1):111-20. https://doi.org/10.1016/j.jad.2013.05.060

20. Patten SB, Williams JV, Lavorato DH, ym. Antidepressant use in Canada has stopped increasing. Can J Psychiatry. 2014;59(11):609-14. https://doi.org/10.1177/070674371405901107

21. Munoz-Arroyo R, Sutton M, Morrison J. Exploring potential explanations for the increase in antidepressant prescribing in Scotland using secondary analyses of routine data. The British journal of general practice : the journal of the Royal College of General Practitioners. 2006;56(527):423-8.

22. Loyola Filho AI, Castro-Costa E, Firmo JO, Peixoto SV. Trends in the use of antidepressants among older adults: Bambui Project. Revista de saude publica. 2014;48(6):857-65. https://doi.org/10.1590/S00348910.2014048005406

23. Ferrari AJ, Charlson FJ, Norman RE, ym. The epidemiological modelling of major depressive disorder: application for the Global Burden of Disease Study 2010. PLoS One. 2013;8(7). https://doi.org/10.1371/journal.pone.0069637

24. de Graaf R, ten Have M, van Gool C, van Dorsselaer S. Prevalence of mental disorders and trends from 1996 to 2009. Results from the Netherlands Mental Health Survey and Incidence Study-2. Soc Psychiatry Psychiatr Epidemiol. 2012;47(2):203-13. https://doi.org/10.1007/s00127-010-0334-8

25. Kessler RC, Berglund P, Demler O, ym. The epidemiology of major depressive disorder: results from the National Comorbidity Survey Replication (NCS-R). JAMA. 2003;289(23):3095105.

https://doi.org/10.1001/jama.289.23.3095

26. Compton WM, Conway KP, Stinson FS, Grant BF. Changes in the prevalence of major depression and comorbid substance use disorders in the United States between 1991-1992 and 2001-2002. Am J Psychiatry. 2006;163(12):2141-7. https://doi.org/10.1176/ajp.2006.163.12.2141

27. Lehtinen V, Joukamaa M, Lahtela K, ym. Prevalence of mental disorders among adults in Finland: basic results from the Mini Finland Health Survey. Acta Psychiatr Scand. 1990;81(5):418-25. https://doi.org/10.1111/j.1600-0447.1990. tb05474.x

28. Lindeman S, Hämäläinen J, Isometsä E, ym. The 12-month prevalence and risk factors for major depressive episode in Finland: representative sample of 5993 adults. Acta Psychiatr Scand. 2000;102(3):178-84. https://doi.org/10.1034/j.16000447.2000.102003178.x 
29. Markkula N, Suvisaari J, Saarni SI, ym. Corrigendum to "Prevalence and correlates of major depressive disorder and dysthymia in an eleven-year follow-up - Results from the Finnish Health 2011 Survey" [J. Affect. Disord. 173 (2015) 73-80]. J Affect Disord. 2017;209:16-7. https://doi.org/10.1016/j.jad.2016.11.007

30. Markkula N, Suvisaari J, Saarni SI, ym. Prevalence and correlates of major depressive disorder and dysthymia in an eleven-year follow-up--results from the Finnish Health 2011 Survey. Journal of affective disorders. 2015;173(March):73-80. https://doi.org/10.1016/j.jad.2014.10.015

31. Wittchen HU, Jacobi F, Rehm J, ym. The size and burden of mental disorders and other disorders of the brain in Europe 2010. Eur Neuropsychopharmacol. 2011;21(9):655-79. https://doi.org/10.1016/j.euroneuro.2011.07.018

32. Blanco C, Okuda M, Markowitz JC, ym. The epidemiology of chronic major depressive disorder and dysthymic disorder: results from the National Epidemiologic Survey on Alcohol and Related Conditions. J Clin Psychiatry. 2010;71(12):164556. https://doi.org/10.4088/JCP.09m05663gry

33. Jacobi F, Hofler M, Strehle J, ym. Twelve-months prevalence of mental disorders in the German Health Interview and Examination Survey for Adults - Mental Health Module (DEGS1-MH): a methodological addendum and correction. Int J Methods Psychiatr Res. 2015. https://doi.org/10.1002/mpr.1479

34. Torikka A, Kaltiala-Heino R, Rimpela A, ym. Self-reported depression is increasing among socioeconomically disadvantaged adolescents - repeated cross-sectional surveys from Finland from 2000 to 2011. BMC Public Health. 2014;14(408).

35. Wahlbeck K, McDaid D. Actions to alleviate the mental health impact of the economic crisis. World Psychiatry. 2012;11(3):139-45. https://doi.org/10.1002/j.2051-5545.2012. tb00114.x

36. Stuckler D, Basu S, Suhrcke M, ym. The public health effect of economic crises and alternative policy responses in Europe: an empirical analysis. Lancet. 2009;374(9686):315-23. https://doi.org/10.1016/S0140-6736(09)61124-7

37. Pirkola S, Isometsä E, Aro H, ym. Childhood adversities as risk factors for adult mental disorders: results from the Health 2000 study. Soc Psychiatry Psychiatr Epidemiol. 2005;40(10):76977. https://doi.org/10.1007/s00127-005-0950-x
38. Park AL, Fuhrer R, Quesnel-Vallee A. Parents' education and the risk of major depression in early adulthood. Soc Psychiatry Psychiatr Epidemiol. 2013;48(11):1829-39. https://doi.org/10.1007/s00127-013-0697-8

39. Paananen R, Santalahti P, Merikukka M, ym. Socioeconomic and regional aspects in the use of specialized psychiatric care--a Finnish nationwide follow-up study. European journal of public health. 2013;23(3):372-7. https://doi.org/10.1093/eurpub/cks147

40. Paananen R, Ristikari T, Merikukka M, ym. Lasten ja nuorten hyvinvointi Kansallinen syntymäkohortti 1987 -tutkimusaineiston valossa. 2012.

41. Reavley NJ, Jorm AF. Willingness to disclose a mental disorder and knowledge of disorders in others: changes in Australia over 16 years. Aust N Z J Psychiatry. 2014;48(2):162-8. https://doi.org/10.1177/0004867413495317

42. Lewer D, O’Reilly C, Mojtabai R, EvansLacko S. Antidepressant use in 27 European countries: associations with sociodemographic, cultural and economic factors. Br J Psychiatry. 2015;207(3):221-6. https://doi.org/10.1192/bjp.bp.114.156786

43. Aromaa E, Tolvanen A, Tuulari J, Wahlbeck K. Predictors of stigmatizing attitudes towards people with mental disorders in a general population in Finland. Nord J Psychiatry. 2011;65(2):125-32. https://doi.org/10.3109/08039488.2010.510206

44. Schwarz AG, McVeigh KH, Hoven C, Kerker BD. Racial and ethnic differences in depression by partner status and the presence of children in the household. Women's health issues : official publication of the Jacobs Institute of Women's Health. 2012;22(6):e553-61.

45. Oh DH, Park JH, Lee HY, ym. Association between living arrangements and depressive symptoms among older women and men in South Korea. Soc Psychiatry Psychiatr Epidemiol. 2015;50(1):133-41. https://doi.org/10.1007/s00127-014-0904-2

\section{NiINA MarkKULA \\ LT, tutkija \\ Psykiatrian tulosyksikkö, HUS/HYKS}

JAANa SuvisaAri

LT, tutkimusprofessori, yksikönpäällikkö

Terveyden ja Hyvinvoinnin laitos

Mielenterveysyksikkö 